\title{
EFFECTS OF DIVALENT CATIONS ON OUT WARD POTASSIUM CURRENTS IN LEECH RETZIUS NERVE CELLS
}

\author{
Zorica Jovanovic, Olgica Mihaljevic, Irena Kostic \\ Department of Pathological Physiology, Faculty of Medical Sciences, University of Kragujevac, Serbia

\begin{abstract}
EFEKTI DVOVALENTNIH KATJONA NA IZLAZNE KALIJUMSKE STRUJE RETZIUSOVIH NERVNIH ĆELIJA PIJAVICE
\end{abstract}

\author{
Zorica Jovanović, Olgica Mihaljević, Irena Kostić \\ Katedra za Patološku fiziologiju, Fakultet medicinskih nauka, Univerzitet u Kragujevcu, Srbija
}

\begin{abstract}
The present study examines the effects of divalent metals, cadmium $\left(\mathrm{Cd}^{2+}\right)$ and manganese $\left(\mathrm{Mn}^{2+}\right)$, on the outward potassium currents of Retzius cells in the hirudinid leeches Haemopis sanguisuga using conventional two-microelectrode voltageclamp techniques. The outward potassium current is activated by depolarization and plays an important role in determining both the neuronal excitability and action potential duration. A strong inhibition of the fast current and a clear reduction in the

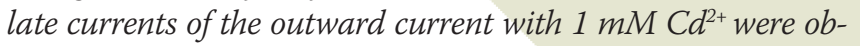
tained, which indicated that both components are sensitive to this metal. Complete blockage of the fast and partial reduction of the slow outward currents was observed after adding $1 \mathrm{mM}$ $\mathrm{Mn}^{2+}$ to the extracellular fluid. These data show that the outward $K^{+}$current in leech Retzius nerve cells comprises at least two components: a voltage-dependent $\mathrm{K}^{+}$current and a $\mathrm{Ca}^{2+}$ activated $\mathrm{K}^{+}$current. These observations also indicate that $\mathrm{Cd}^{2+}$ is more effective than $\mathrm{Mn}^{2+}$ in blocking ion flow through these channels and that suppressing $\mathrm{Ca}^{2+}$-activated $\mathrm{K}^{+}$outward currents can prolong the action potential in nerve cells.
\end{abstract}

Key word: Retzius neuron, cadmium, manganese, outward potassium currents

\section{SAŽETAK}

Ispitivana su dejstva dvovalentnih katjona, kadmijuma $\left(\mathrm{Cd}^{2+}\right)$ i mangana $\left(\mathrm{Mn}^{2+}\right)$ na izlazne ispravljačke kalijumske struje Retziusovih nervnih ćelija pijavice, Haemopis sanguisuga, tehnikom nametnutog napona sa dve mikroelektrode. Depolarizacijom izazvane izlazne kalijumske struje imaju značajnu ulogu u determinaciji nadražljivosti nervnih ćelija

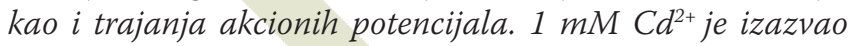
blokadu brze i redukciju kasne komponente izlazne kalijumske struje, što ukazuje da su obe komponente senzitivne

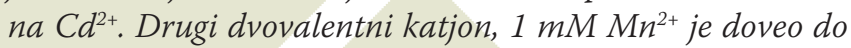
kompletne blokade brze i delimične inhibicije spore komponente izlazne kalijumske struje. Rezultati ovog istraživanja ukazuju da su izlazne kalijumske struje u Retziusovim nervnim ćelijama pijavice sastavljene od najmanje dve komponente: naponsko-zavisne i kalcijumsko-aktivisane kalijumske struje. Rezultati studije potvrduju da je $\mathrm{Cd}^{2+}$ efikasniji blokator izlaznih kalijumskih kanala od $\mathrm{Mn}^{2+}$, kao i da inhibicija kalcijumsko-aktivisanih kalijumskih struja može biti odgovorna za prolongiranje trajanja akcionih potencijala.

Ključne reči: Retziusov neuron, kadmijum, mangan, izlazne kalijumske struje.

\section{INTRODUCTION}

Divalent cations (such as $\mathrm{Cd}^{2+}, \mathrm{Co}^{2+}, \mathrm{Ni}^{2+}, \mathrm{Fe}^{2+}$ and $\mathrm{Mn}^{2+}$ ) are known as nonspecific calcium $\left(\mathrm{Ca}^{2+}\right)$ channel antagonists that block $\mathrm{Ca}^{2+}$ channels to varying degrees. Additionally, divalent metals are among the classical tools that have been used to investigate the activation and deactivation kinetics and the permeation of the potassium $\left(\mathrm{K}^{+}\right)$current (1). Cadmium $\left(\mathrm{Cd}^{2+}\right)$ is a nonessential divalent metal ion that can cause cytotoxicity in multiple organs, includ- ing the brain. Recently, a great amount of scientific data has been used in attempts to define the mechanism of action of $\mathrm{Cd}^{2+}$ in brain. However, the mechanisms underlying $\mathrm{Cd}^{2+}$ neurotoxicity remain not entirely understood. Multiple scientific studies have shown that the toxic effects of $\mathrm{Cd}^{2+}$ on the nervous system are manifold. For example, Lopez et al (2) demonstrated that in cultured cortical neurons, a low concentration of $\mathrm{Cd}^{2+}(100 \mathrm{nM})$ induced apop- 
tosis, whereas higher concentrations $(100 \mathrm{mM})$ produced necrotic cell death. More recent studies (3) have reported that $\mathrm{Cd}^{2+}$ toxicity in cerebral cortical neurons is mediated by intracellular $\mathrm{Ca}^{2+}$ elevation, which triggers the activation of the apoptotic signalling pathway in mitochondria. Additionally, the cellular toxicity generated by $\mathrm{Cd}^{2+}$ is due, in part, to the generation of reactive oxygen species (ROS) that depolarize the mitochondrial membrane potential and decrease the ATP levels (4).

Some novel studies have revealed the endoplasmic reticulum to be the cellular target of $\mathrm{Cd}^{2+}$ toxicity. The $\mathrm{Cd}^{2+}$-induced release of $\mathrm{Ca}^{2+}$ from endoplasmic reticulum occurs via the inositol trisphosphate $\left(\mathrm{IP}_{3}\right)$ pathway (5). In contrast, $\mathrm{Cd}^{2+}$ inhibition of the electron transport chain in mitochondria generates reactive oxygen species (ROS) and activates caspase-9. These pathways appear to be simultaneously activated, and their synergistic activation can promote apoptosis through the production of ROS and $\mathrm{Ca}^{2+}$-mitochondria signalling (6). According to Smith et al. (7), $\mathrm{Cd}^{2+}$ rapidly increases $\mathrm{IP}_{3}$, which is known to mobilize stored $\mathrm{Ca}^{2+}$. Furthermore, they showed that $\mathrm{Cd}^{2+}$ and other divalent metals increased $\mathrm{IP}_{3}$ and mobilized intracellular $\mathrm{Ca}^{2+}$. Yang et al (8) demonstrated that $\mathrm{Cd}^{2+}$ induces necrotic cell death by increasing both the intracellular $\mathrm{Ca}^{2+}$ concentration and the ROS level. Experimental studies have shown that $\mathrm{Cd}^{2+}$-induced apoptosis is mediated by the $\mathrm{Ca}^{2+}$ signalling pathway and that $\mathrm{Ca}^{2+}$-mediated apoptosis occurs through the mitochondria-caspase signalling pathway (3). Recent studies have reported that, similar to other toxic metals, $\mathrm{Cd}^{2+}$ impairs neurogenesis and physiological signal transduction (9). Additionally, evidence is growing that $\mathrm{Cd}^{2+}$ exposure can alter gene expression and cause an epigenetic effect. One possible mechanistic pathway for $\mathrm{Cd}^{2+}$-induced toxicity is through the modification of hormone levels by affecting the hypothalamic-pituitary-gonadal axis $(10,11)$.

In contrast to $\mathrm{Cd}^{2+}$, which is a nonessential metal, manganese $\left(\mathrm{Mn}^{2+}\right)$ is an essential trace element that is ubiquitous and pivotal for normal cell function and metabolism. Nevertheless, excessive accumulation of $\mathrm{Mn}^{2+}$ in the brain may lead to a condition known as manganism, a neurodegenerative disorder associated with dysfunctions in the basal ganglia that causes parkinsonian-like symptoms (1214). Recent studies have reported that $\mathrm{Mn}^{2+}$-induced neurotoxicity is mediated, at least in part, by the generation of ROS, depletion of antioxidant defence mechanisms and mitochondrial dysfunction (15).

The purpose of this study was to investigate the components of the somatic outward current and determine the relationship between the $\mathrm{Ca}^{2+}$ and voltage-dependent $\mathrm{K}^{+}$currents on the basis of ion-substitution experiments. According to the activation and deactivation kinetics, the $\mathrm{Ca}^{2+}$-activated $\mathrm{K}^{+}$current could be separated into two distinct components: a fast transient and a slow current. The leech served as an appropriate model for studying ion channels because of the extreme structural simplicity of its nervous system.

\section{MATERIALS AND METHODS}

\section{Experimental animals}

The experiments were performed utilizing Retzius nerve cells from the first ten abdominal ganglia of the leech, Haemopis sanguisuga (commonly known as the horse-leech). The dissection method was similar to that described previously $(17,18)$. The 21 segmental ganglia contain $\sim 400$ neurons arranged in six packets. Retzius neurons are the largest cells $(\sim 60 \mu \mathrm{m}$ diameter of the soma) located on the ventral side of the ganglia. They were identified by their large cell bodies, position and firing properties $(17,19)$. Isolated ganglia of the Retzius neurons have resting potentials that range from - 40 to $-60 \mathrm{mV}$ and amplitude action potentials that range from 30 to $50 \mathrm{mV}$, and they fire spontaneously at a slow rate $(0.2-3 \mathrm{APs} / \mathrm{sec})$.

\section{Electrophysiological technique}

All electrophysiological recordings were made at room temperature $\left(20-24^{\circ} \mathrm{C}\right)$ under two-electrode voltage-clamp conditions. The electrical arrangement for voltage clamping utilized was based on the theoretical principles developed for different cellular membranes (20). Retzius neurons were impaled with two electrolyte-filled microelectrodes to record membrane potential and to perform the current injection. For the intracellular recordings, we used glass micropipettes pulled from borosilicate glass (1.5 $\mathrm{mm}$ outside diameter, $0.6 \mathrm{~mm}$ inside diameter, Clark Electromedical Instruments, Edenbridge, UK) filled with $3 \mathrm{M}$ $\mathrm{KC} 1$ (resistance $\sim 20 \mathrm{M} \Omega$ ). Electrodes were connected to a voltage-clamp amplifier (Bioelectric Instrument model DS2C). The bath was grounded via an agar bridge. Command pulses were derived from a Tektronix 161 pulse generator. Voltage and current recordings were displaced on a Tektronix 564 oscilloscope. Output signals were digitized by an A/D converter (Axon Instruments, Jakarta, Indonesia) and were saved before being analysed on a computer running in-house acquisition software.

Briefly, the difference between the membrane potential and the command pulse was amplified, and the resulting voltage was used to drive the current across the membrane via the microelectrode. The membrane potential was measured between the second electrode and the ground. In the voltage-clamp recording mode, depolarization from a holding potential of $-70 \mathrm{mV}$ elicited outward currents that increased to steady-state values.

\section{Solutions}

During the experiment, isolated ganglia were superfused, initially with normal leech saline of the following composition (in mM): $115 \mathrm{NaCl}, 4 \mathrm{KCl}, 2 \mathrm{CaCl}_{2}, 1.2 \mathrm{Na}_{2} \mathrm{H}-$ $\mathrm{PO}_{4}, 0.3 \mathrm{NaH}_{2} \mathrm{PO}_{4}$ (pH 7.2). The sodium-free Ringer contained $115 \mathrm{mM}$ TRIS-Cl (Tris Ringer) instead of $\mathrm{NaCl}$ and phosphate buffer. $\mathrm{CdCl}_{2}(1 \mathrm{mM})$ and $\mathrm{MnCl}_{2}(1 \mathrm{mM})$ were 


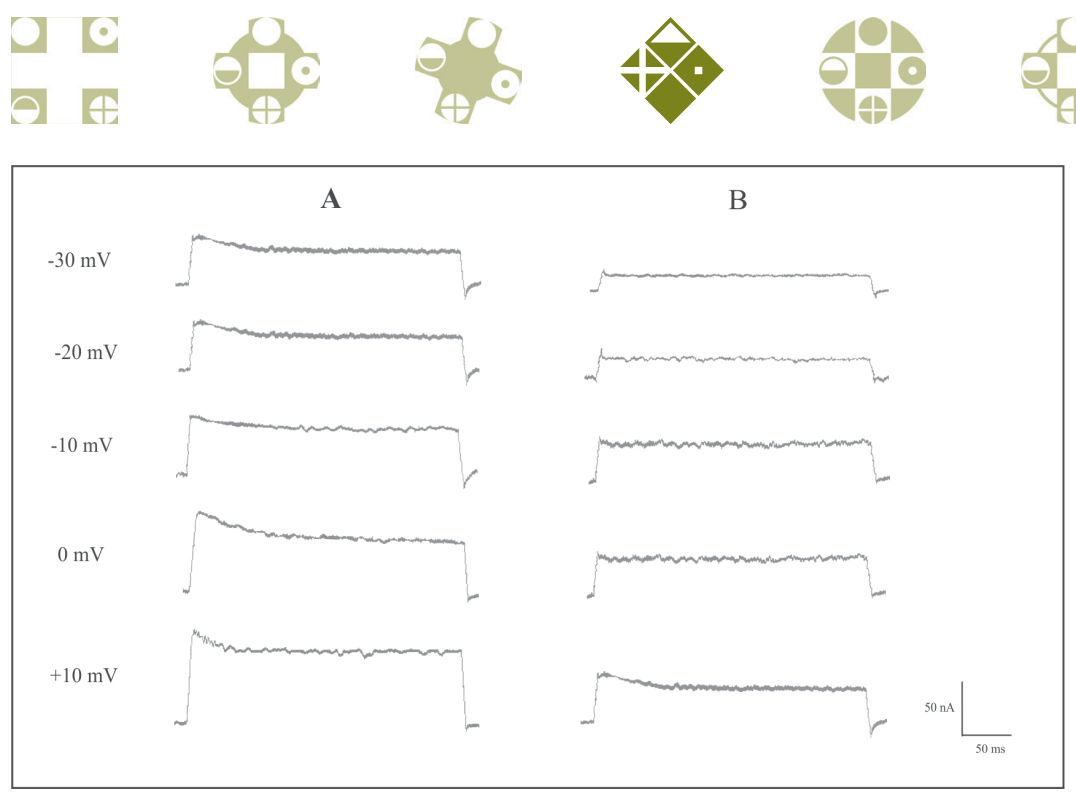

Figure 1. Representative current recordings obtained under long-lasting stimulation (300 ms) in Tris Ringer (A) and at $10 \mathrm{~min}$ after adding $1 \mathrm{mM}$ $\mathrm{CdCl}_{2}$ to the Tris Ringer (B) during the displacement of the holding potential from $-70 \mathrm{mV}$ to the potential given at each trace.

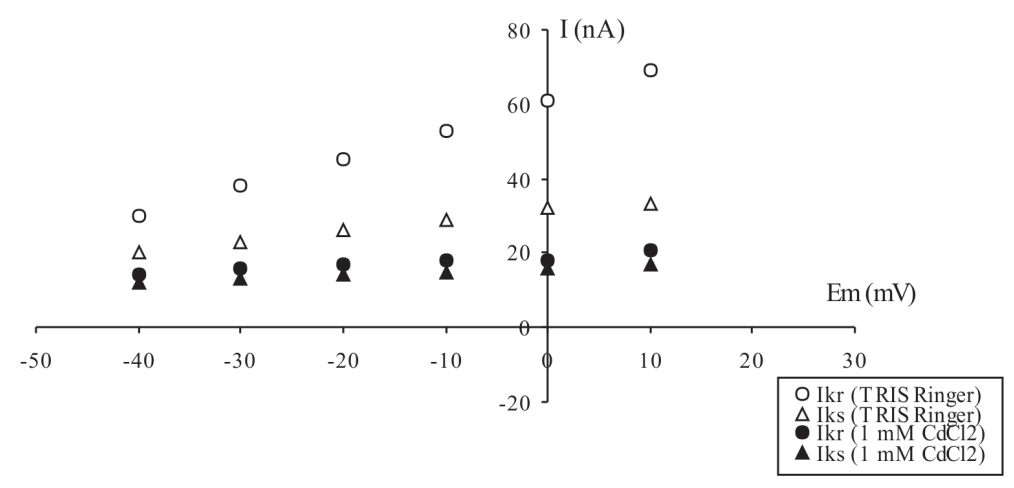

Figure 2. The current-voltage relationship at the peak of the outward $\mathrm{K}^{+}$current in the absence (open symbols) and presence (solid symbols) of $1 \mathrm{mM}$ $\mathrm{CdCl}_{2}$.

Ikr- rapid outward $\mathrm{K}^{+}$current; Iks-slow outward $\mathrm{K}^{+}$ current.

used as blockers of outward potassium channels and added to the normal or Tris Ringer solution. $\mathrm{CdCl}_{2}$ and $\mathrm{MnCl}_{2}$ were purchased from Sigma-Aldrich (St. Louis, MO, USA). The bath volume was $2 \mathrm{ml}$, and the solution changes were completed within $30 \mathrm{sec}$.

\section{Statistical analysis}

Statistical analysis was performed using Student's t-test for paired correlated samples. Currents (in nA) in the presence and absence of $\mathrm{CdCl}_{2}$ and $\mathrm{MnCl}_{2}$ were compared for each Retzius nerve cell.

\section{RESULTS}

\section{The effect of $\mathrm{Cd}^{2+}$ on the outward $\mathrm{K}^{+}$current of leech Retzius nerve cells}

In the first series of experiments, we examined the effect of the $\mathrm{Ca}^{2+}$ channel blocker, $\mathrm{Cd}^{2+}(1 \mathrm{mM})$, on the membrane $\mathrm{K}^{+}$current in Retzius neurons. The outward $\mathrm{K}^{+}$currents, which contribute to the resting membrane potential and repolarization of the action potential, were studied in voltage-clamped leech Retzius neurons. The $\mathrm{K}^{+}$current was activated by depolarization with the sodium-free Ringer (TRIS Ringer) with long-lasting stimulation $(300 \mathrm{~ms})$ by an activated outward current. From $-70 \mathrm{mV}$, depolarizing steps to a potential of approximately $-40 \mathrm{mV}$ elicited a fast outward current. This transient part of the total outward current had rapid activation kinetics and inactivated within $50 \mathrm{~ms}$. Higher depolarization produced a larger current and a slow outward current that showed little inactivation. The measurements of the outward $\mathrm{K}^{+}$currents (in $\mathrm{nA}$ ) in the control condition (TRIS Ringer) were compared with those in the $\mathrm{Cd}^{2+}$ condition for each Retzius cell.

The voltage-clamp experiments demonstrated that $\mathrm{Cd}^{2+}(1 \mathrm{mM})$ reduced both types of outward currents, with different efficacies. The fast outward current, activated by small depolarizations (i.e., at $-35 \mathrm{mV}$ ), was more sensitive to $\mathrm{Cd}^{2+}$ than was the slow part of the outward current activated by larger depolarizations. Typical current-voltage records were obtained upon replacing sodium with Tris (A) and at $10 \mathrm{~min}$ after adding $1 \mathrm{mM} \mathrm{Cd}^{2+}(\mathrm{B})$ to Tris Ringer after displacing the membrane potential from a resting level of $-40 \mathrm{mV}$, as shown in Fig. 1. A strong inhibition of the fast current and an evident reduction in the late currents of the outward current with $1 \mathrm{mM} \mathrm{Cd}^{2+}$ were observed, which indicated that both components are sensitive to this metal.

To investigate the relationship between the change in the outward potassium current with the change in voltage (I-V), the membrane potential was increased from a holding potential of $-70 \mathrm{mV}$ to five potentials, ranging from -40 to $+10 \mathrm{mV}$ in $10 \mathrm{mV}$ increments (Fig. 2). In the presence 


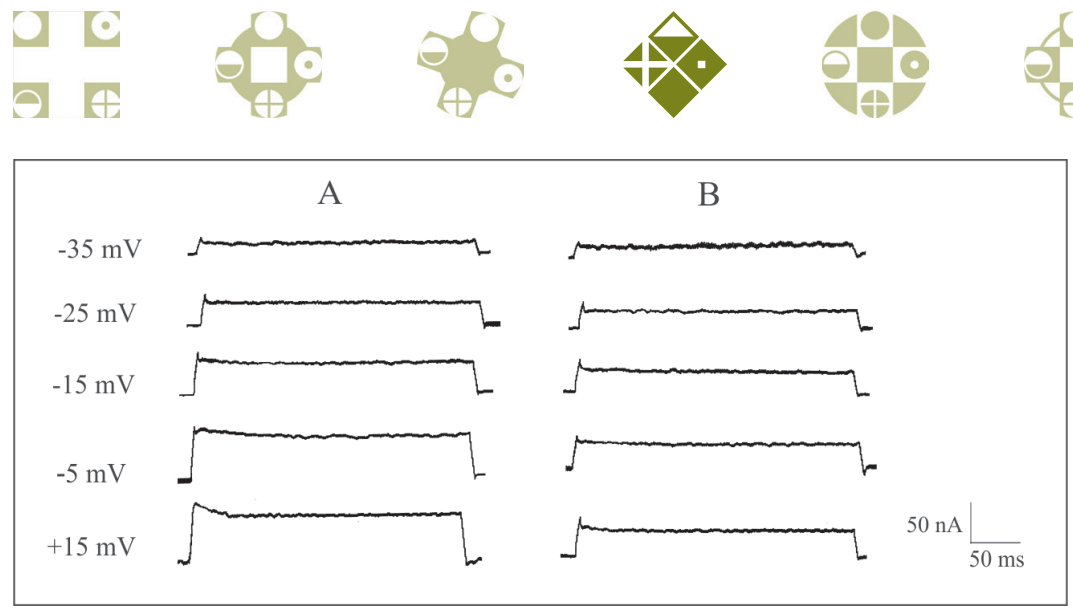

Figure 3. Patterns of voltage clamp current recordings in a leech Retzius nerve cell in Tris Ringer (A) and at $10 \mathrm{~min}$ after adding $1 \mathrm{mM} \mathrm{MnCl}$ (B). Potentials were increased from the holding potential (-70 $\mathrm{mV}$ ) to the potential given on each trace.

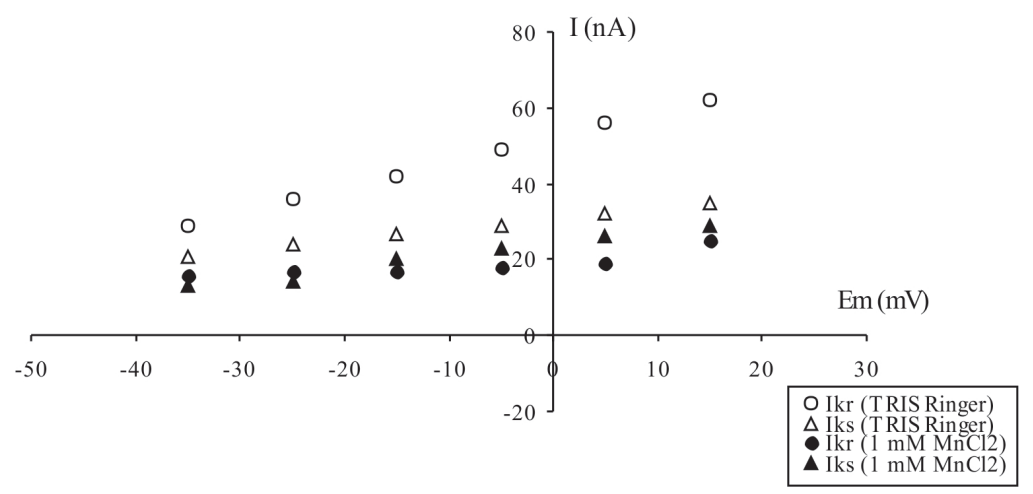

Figure 4. The current-voltage relationship at the peak of the outward $\mathrm{K}^{+}$current in the absence (open symbols) and presence (solid symbols) of $1 \mathrm{mM}$ $\mathrm{MnCl}_{2}$.

Ikr- rapid outward $\mathrm{K}^{+}$current; Iks-slow outward $\mathrm{K}^{+}$ current.

of $1 \mathrm{mM} \mathrm{Cd}^{2+}$, at the test potential of $+10 \mathrm{mV}$, the fast and slow parts of the $\mathrm{K}^{+}$outward current were reduced from 69 to $21 \mathrm{nA}(69.57 \%)$ and from 33 to $17 \mathrm{nA}$ (48.49\%), respectively.

\section{The effect of $\mathrm{Mn}^{2+}$ on the outward $\mathrm{K}^{+}$current of leech Retzius nerve cells}

To determine the total outward current in terms of their voltage and calcium-dependent components, experiments using another $\mathrm{Ca}^{2+}$ channel blocker, $\mathrm{Mn}^{2+}$, were performed.

In contrast to the previous experiments with $\mathrm{Cd}^{2+}$, $\mathrm{Mn}^{2+}$ was effective only in blocking the fast but not the late outward current. Voltage-clamp experiments were performed on freshly dissociated Retzius neurons in the TRIS Ringer (A), and at $10 \mathrm{~min}$ after adding $\mathrm{Mn}^{2+}(1 \mathrm{mM})$ to the Tris Ringer solution (B). Typical membrane current pattern curves that were produced by increasing the depolarization from a steady holding level of $-70 \mathrm{mV}$ are shown in Fig 3. Clearly, both components were affected, and the fast transient part was completely reduced.

Figure 4 shows the corresponding current-voltage (I$\mathrm{V})$ relationship that was obtained with $1 \mathrm{mM} \mathrm{Mn}^{2+}$. In the presence of $\mathrm{Mn}^{2+}$, at the test potential of $+15 \mathrm{mV}$, the fast and slow parts of the $\mathrm{K}^{+}$outward current were reduced from 62 to $25 \mathrm{nA}(59.68 \%)$ and from 35 to $29 \mathrm{nA}(17.15 \%)$, respectively. The data obtained with $\mathrm{Mn}^{2+}$ support the view that both the fast and partially slowed outward current are $\mathrm{Ca}^{2+}$ activated.

\section{DISCUSSION}

The results reported in this paper show that the outward $\mathrm{K}^{+}$current in leech Retzius nerve cells is composed of two distinct components: a voltage-dependent current and a $\mathrm{Ca}^{2+}$-activated $\mathrm{K}^{+}$current. The $\mathrm{Ca}^{2+}$-activated $\mathrm{K}^{+}$current plays a key role in regulating neuronal excitability. In this study, the addition of inorganic $\mathrm{Ca}^{2+}$ channel blockers $\left(\mathrm{Cd}^{2+}\right.$ or $\left.\mathrm{Mn}^{2+}\right)$ was used to demonstrate the dependence of $\mathrm{Ca}^{2+}$ on outward $\mathrm{K}^{+}$currents.

Recent, much of our knowledge of membrane transporters has been acquired by studying the interaction of blocking agents and ionic channels. The voltage dependent conductance of electrically excitable membranes has been extensively studied by several different approaches. The classic study by Hodgkin and Huxley (16) led to a conclusion on the existence of two independent membrane conductance: early $\mathrm{Na}^{+}$and late $\mathrm{K}^{+}$conductance. However, the conductances of other tissues appeared to be more numerous than those found in the squid giant axon. In spite of the difficulties in separation, several outward currents have been identified, such as the slow and fast $\mathrm{K}^{+}$currents and $\mathrm{Ca}^{2+}$-activated $\mathrm{K}^{+}$currents.

Leech ganglion cells have been recognized as a promising model system for electrophysiological studies because the size and accessibility of these neurons allow them to be readily implanted with several microelectrodes. In leech Retzius nerve cells, $\mathrm{Ca}^{2+}$ activated $\mathrm{K}^{+}$ currents are large outward $\mathrm{K}^{+}$currents $(17,18)$. Electro- 
physiological studies have shown that membrane transport proteins are susceptible to divalent cations (such as $\mathrm{Cd}^{2+}, \mathrm{Co}^{2+}, \mathrm{Ni}^{2+}, \mathrm{Fe}^{2+}$ and $\left.\mathrm{Mn}^{2+}\right)$. To date, most research has focused on the toxic effects of $\mathrm{Cd}^{2+}$ on the brain, with only a few experimental studies on the effects of $\mathrm{Mn}^{2+}$ on outward $\mathrm{K}^{+}$currents. Although the molecular mechanisms of action of $\mathrm{Cd}^{2+}$ on ion transporters are not fully understood, several hypotheses have been proposed. One possibility is that $\mathrm{Cd}^{2+}$ may mimic other metals (and elements) at the site of the membrane transporters or channels in the nerve cell membrane (21). Several lines of evidence suggest that $\mathrm{Cd}^{2+}$ is transported into neurons and other cells via transporters for naturally occurring cations, such as $\mathrm{Ca}^{2+}$ ("ionic mimicry") (21, 22). Zalups and Ahmad (22) proposed the mechanism of $\mathrm{Cd}^{2+}$ transport into a cell. This uptake has been recently proposed to occur through a mechanism of ionic mimicry, whereby $\mathrm{Cd}^{2+}$ mimics the divalent cation species of one or more of these nutritive metals at the binding site of one or more carrier proteins and/or channels that transport these metals. One possible pathway for $\mathrm{Cd}^{2+}$ entry into a cell is via $\mathrm{Ca}^{2+}$ channels in the plasma membrane (including both voltage-gated and receptor-dependent $\mathrm{Ca}^{2+}$ channels), thus leading to the accumulation of $\mathrm{Cd}^{2+}$ in the cell and, finally, the induction of caspase-12-mediated apoptosis (5).

In recent years, new electrophysiological studies have indicated that $\mathrm{Cd}^{2+}$ may interact with ion channels and transporters. Considering nerve cell function, $\mathrm{Cd}^{2+}$ can attack ion channels either directly or indirectly by disrupting the physiological signal cascades $(5,23,24) . \mathrm{Cd}^{2+}$ is a well-known specific blocker of $\mathrm{Ca}^{2+}$ channels and inhibits $\mathrm{Ca}^{2+}$ cellular uptake. Electrophysiological investigations in various experimental models have shown that $\mathrm{Cd}^{2+}$ is commonly used to block voltage-dependent $\mathrm{Ca}^{2+}$ currents (25) and $\mathrm{Ca}^{2+}$-activated $\mathrm{K}^{+}$currents (26-29). In rat pyramidal neurons (26), $200 \mu \mathrm{M}$ cadmium was found to markedly reduce the early and late components of $\mathrm{Ca}^{2+}$-activated $\mathrm{K}^{+}$current $\left(\mathrm{I}_{\mathrm{K}(\mathrm{Ca})}\right) \cdot \mathrm{Cd}^{2+}$ is classically considered a $\mathrm{Ca}^{2+}$ channel blocker, but previous studies have demonstrated that $\mathrm{Cd}^{2+}(200 \mu \mathrm{M})$ does not affect the depolarization-activated outward current (27). However, Sah et al. (30) demonstrated that $\mathrm{Cd}^{2+}$ at concentrations of 0.1-0.5 mM had no effect on the $\mathrm{K}^{+}$current of guinea pig neurons, whereas at higher concentrations $(2 \mathrm{mM})$, it induced a reduction of the outward current. In the present study, we found that $\mathrm{Cd}^{2+}$ significantly affected the fast and late membrane currents. In contrast, $\mathrm{Mn}^{2+}$ blocked the fast transient outward current in leech Retzius nerve cells. The results obtained with $\mathrm{Mn}^{2+}$ support the theory that the fast and partially slow outward currents are $\mathrm{Ca}^{2+}$ activated. Our voltage-clamp data support the early proposal of Beleslin (17) and Stewart (18) on the existence of $\mathrm{Ca}^{2+}$-activated $\mathrm{K}^{+}$channels in leech neurons. Interestingly, similar results were found by Mitra and Morad (28), who reported that nifedipine and cadmium reduced the $\mathrm{Ca}^{2+}$-activated $\mathrm{K}^{+}$current.
Jow and Numann (31) show that $5 \mathrm{mM} \mathrm{Mn}^{2+}$ reduced large inward rectifier current $\left[\mathrm{I}_{\mathrm{K}(\mathrm{IR})}\right]$ by $33 \%$ in human capillary endothelial cells, and similar results in rat pyramidal neurons were obtained by Castelli et al (32) using the patch-clamp technique. Castelli et al. reported that $\mathrm{Mn}^{2+}$, in addition to performing a blocking action on high-voltage-activated $\mathrm{Ca}^{2+}$ channels, modified the $\mathrm{Ca}^{2+}$ current activation and deactivation kinetics.

Taken together, we can conclude that the total outward $\mathrm{K}^{+}$current is composed of two distinct components in leech Retzius nerve cells, i.e., voltage dependent and $\mathrm{Ca}^{2+}$-activated $\mathrm{K}^{+}$currents, and that the $\mathrm{Ca}^{2+}$ activated $\mathrm{K}^{+}$ current is a large outward $\mathrm{K}^{+}$current.

\section{Conflict of Interest}

All of the authors declare no conflict of interest.

\section{REFERENCES}

1. Hllle B. lonic Channels of Excitable Membranes. 1992. Sinauer Associates, Inc. Sunderland, Massachusetts.

2. Lopez E, Figueroa S, Oset-Gasque MJ, Gonzalez MP. Apoptosis and necrosis: two distinct events induced by cadmium in cortical neurons in culture. Br J Pharmacol. 2003; 138(5): 901-11.

3. Yuan Y, Jiang CY, Xu H, Sun Y, Hu FF, Bian JC, Liu XZ, $\mathrm{Gu}$ JH, Liu ZP. Cadmium-induced apoptosis in primary rat cerebral cortical neurons culture is mediated by a calcium signaling pathway. PLoS One, 2013; 8(5): e64330. doi: 10.1371/journal.pone. 0064330.

4. Lopez E, Arce C, Oset-Gasque MJ, Canadas S, Gonzalez MP. Cadmium induces reactive oxygen species generation and lipid peroxidation in cortical neurons in culture. Free Radic Biol Med. 2006; 40(6): 940-51.

5. Biagioli M, Pifferi S, Ragghianti M, Bucci S, Rizzuto R, Pinton P. Endoplasmic reticulum stress and alteration in calcium homeostasis are involved in cadmium-induced apoptosis. Cell Calcium, 2008; 43(2): 184-95.

6. Wang B, Du Y. Cadmium and its neurotoxic effects. Oxid Med Cell Longev. 2013; 2013: 898034. doi: 10.1155/2013/898034.

7. Smith JB, Dwyer SD, Smith L. Cadmium evokes inositol polyphosphate formation and calcium mobilization. Evidence for a cell surface receptor that cadmium stimulates and zinc antagonizes. J Biol Chem. 1989; 264(13): 7115-8.

8. Yang PM, Chen HC, Tsai JS, Lin LY. Cadmium induces $\mathrm{Ca} 2+$-dependent necrotic cell death through calpaintriggered mitochondrial depolarization and reactive oxygen species-mediated inhibition of nuclear factorkappaB activity. Chem Res Toxicol. 2007; 20(3): 406-15.

9. Son J, Lee SE, Park BS, Jung J, Park HS, Bang JY, Kang GY, Cho K. Biomarker discovery and proteomic evaluation of cadmium toxicity on collembolan species, Paronychiurus kimi (Lee). Proteomics, 2011; 11(11): 2294-307. 
10. Lafuente A, Gonzalez-Carracedo A, Romero A, Can P, Esquifino AI. Cadmium exposure differentially modifies the circadian patterns of norepinephrine at the median eminence and plasma LH, FSH and testosterone levels. Toxicol Lett. 2004; 146(2): 175-82.

11. Vetillard A, Bailhache T. Cadmium: an endocrine disrupter that affects gene expression in the liver and brain of juvenile rainbow trout. Biol Reprod. 2005; 72(1): 119-26.

12. Avila DS, Puntel RL, Aschner M. Manganese in health and disease. Met Ions Life Sci. 2013; 13: 199-227. doi: 10.1007/978-94-007-7500-8-7.

13. Bouabid S, Tinakoua A, Lakhdar-Ghazal N, Benazzouz A. Manganese Neurotoxicity: behavioral disorders associated with dysfunctions in the basal ganglia and neurochemical transmission. J Neurochem. 2015; doi: 10.1111/jnc. 13442 .

14. Kwakye GF, Paoliello MM, Mukhopadhyay S, Bowman AB, Aschner M. Manganese-Induced Parkinsonism and Parkinson's Disease: Shared and Distinguishable Features. Int J Environ Res Public Health, 2015; 12(7): 7519-40. doi: 10.3390/ijerph120707519.

15. Martinez-Finley EJ, Gavin CE, Aschner M, Gunter TE. Manganese neurotoxicity and the role of reactive oxygen species. Free Radic Biol Med. 2013; 62: 65-75. doi: 10.1016/j.freeradbiomed.2013.01.032.

16. Hodgkin AL, Huxley AF. A quantitative description of membrane current and its application to conduction and excitation in nerve. J Physiol. 1952; 117(4): 500-44.

17. Beleslin BB, Ristanovic D, Osmanovic S. Somatic outward currents in voltage clamp leech Retzius nerve cell. Comp Biochem Physiol. 1988; 89: 187-96.

18. Stewart RR, Nicholls JG, Adams WB. Na+, K+ and $\mathrm{Ca} 2+$ currents in identified leech neurones in culture. J Exp Biol. 1989; 141: 1-20.

19. Lent CM. The Retzius cells within the central nervous system of leeches. Prog Neurobiol. 1977; 8: 81-117.

20. Katz GM, Schwartz TL. Temporal control of voltageclamped membranes: an examination of principles. Membr Biol. 1974; 17(3): 275-91.
21. Bridges CC, Zalups RK. Molecular and ionic mimicry and the transport of toxic metals. Toxicol Appl Pharmacol. 2005; 204(3): 274-308.

22. Zalups RK, Ahmad S. Molecular handling of cadmium in transporting epithelia. Toxicol Appl Pharmacol. 2003; 186(3): 163-88.

23. Thevenod F. Cadmium and cellular signaling cascades: to be or not to be? Toxicol Appl Pharmacol. 2009; 238(3): 221-39.

24. Thevenod F, Lee WK. Cadmium and cellular signaling cascades: interactions between cell death and survival pathways. Arch Toxicol. 2013; 87(10): 1743-86.

25. Lopin KV, Thevenod F, Page JC, Jones SW. $\mathrm{Cd}^{2+}$ block and permeation of CaV3.1 ( $\left.\alpha 1 \mathrm{G}\right)$ T-type calcium channels: candidate mechanism for $\mathrm{Cd}^{2+}$ influx. Mol Pharmacol. 2012; 82(6): 1183-93.

26. Aoki T, Baraban SC. Properties of a calcium-activated $\mathrm{K}+$ current on interneurons in the developing rat hippocampus. J Neurophysiol. 2000; 83(6): 3453-61.

27. Mayer EA, Loo DD, Snape WJ, Sachs G. The activation of calcium and calcium-activated potassium channels in mammalian colonic smooth muscle by substance P. J Physiol. 1990; 420: 47-71.

28. Mitra R, Morad M. Ca2+ and Ca2+-activated K+ currents in mammalian gastric smooth muscle cells. Science, 1985; 229(4710): 269-72.

29. Kawasaki S, Kimura S, Watanabe S, Fujita R, Matsumoto M, Sasaki K. Augmentinf effect of serotonin on the voltage-dependent $\mathrm{Ca} 2+$ current and subsequently activated $\mathrm{K}+$ current in Aplysia neurons. Tohoku J Exp Med. 2007; 211(1): 31-41.

30. Sah P, Gibb AJ, Gage PW. Potassium current activated by depolarization of dissociated neurons from adult guinea pig hippocampus. J Gen Physiol. 1988; 92(2): 263-78.

31. Jow F, Numann R. Divalent ion block of inward rectifier current in human capillary endothelial cells and effects on resting membrane potential. J Physiol. 1998; 512(1): 119-28.

32. Castelli L, Tanzi F, Taglietti V, Magistretti J. Cu2+, $\mathrm{Co} 2+$, and $\mathrm{Mn} 2+$ modify the gating kinetics of highvoltage-activated $\mathrm{Ca} 2+$ channels in rat palaeocortical neurons. J Membr Biol. 2003; 195(3): 121-36. 